\title{
Consequences of occupational asthma on employment and financial status: a follow-up study
}

\author{
J. Ameille, J.C. Pairon, M.C. Bayeux, P. Brochard, D. Choudat, F. Conso, \\ A. Devienne, R. Garnier, Y. Iwatsubo
}

Consequences of occupational asthma on employment and financial status: a followup study. J. Ameille, J.C. Pairon, M.C. Bayeux, P. Brochard, D. Choudat, F. Conso, A. Devienne, R. Garnier, Y. Iwatsubo. (CERS Journals Ltd 1997.

ABSTRACT: The aim of this study was to describe changes in employment and income following a diagnosis of occupational asthma, and to determine what factors might affect these changes.

Two hundred and nine patients with occupational asthma were reviewed on average 3.1 yrs after the diagnosis had been made. They were contacted by telephone or were sent a self-administered questionnaire by post. Multiple logistic regression models were constructed to determine which variables were associated with loss of employment after the diagnosis.

At the time of review, $44 \%$ of patients had left their previous job and $25 \%$ were currently unemployed. Remarkably, 32\% remained exposed to the offending agents in the same job. Forty six percent of the patients had suffered a reduction of income $(84 \%$ of those who had left their employer versus $19 \%$ of those still employed in the same company $(\mathbf{p}<0.001))$. Claims for compensation, size of the company, level of education, and age at the time of diagnosis were significantly associated with a risk for becoming unemployed or having a new employer after the diagnosis of occupational asthma.

Occupational asthma results in severe socioeconomic consequences. The French compensation system for occupational asthma should be revised, as the criteria currently used to determine compensation for this disease largely underestimate the social and occupational damages.

Eur Respir J., 1997; 10: 55-58.

Occupational asthma is now the commonest occupational respiratory disease in industrialized countries [1, 2]. This condition mainly affects young and economically active patients and may result in serious respiratory disability. Many studies have been devoted to the medical aspects of occupational asthma, but few have investigated its socioeconomic consequences [3-10]. The aim of the present study was to describe changes in employment and income following a diagnosis of occupational asthma, and to determine what factors might affect these changes.

\section{Patients and methods}

The study population consisted of 257 subjects referred to occupational medicine departments in Paris and surrounding areas for occupational asthma. The diagnosis, made between January 1989 and December 1993, was based on a history of respiratory symptoms that improved on days away from work, and generally on at least one other confirmatory investigation, including serial peak expiratory flow measurements, bronchial provocation test, and specific immunoglobulin E (IgE) radio allergosorbent test. Baseline data were obtained from case records, including sociodemographic information (age, sex, nationality, marital status, educational
Institut Interuniversitaire de Médecine du Travail de Paris Ile-de-France, Paris, France.

Correspondence: J. Ameille Hôpital Raymond Poincaré 92380 Garches France

Keywords: Compensation employment occupational asthma

Received: March 251995

Accepted after revision August 231996 level, professional qualification), and medical information (mean duration of symptoms before diagnosis, causative agent, pulmonary function tests). The severity of asthma was assessed by means of a score based on the following items: hospital admissions; frequency of asthma symptoms; past and current use of steroids and/or other asthma medications [11]. Additional information concerning the professional activity at the time of diagnosis was also obtained from case records: type of employment, number of employees in the company.

An attempt was made to recontact all patients at least 1 year after the initial diagnosis. Most were contacted for an interview by telephone. Those who could not be traced by phone were sent a self-administered questionnaire by post. The information requested concerned the current working status, financial situation and whether a compensation claim had been submitted.

Of the 257 subjects, 209 could be traced on average 3 yrs after the diagnosis of occupational asthma (mean \pm SEM $=3.1 \pm 2.2 \mathrm{yrs}$ ). Results will be presented for these 209 subjects.

\section{Analysis}

The consequences of occupational asthma were analysed, essentially, in terms of employment status. The 
subjects were classified into two categories, according to whether or not they had lost their initial job following the diagnosis of occupational asthma.

Values for continuous variables were expressed as the mean \pm SEM. Chi-squared test and Student's t-test were used for univariate analysis. A p-value less than 0.05 was considered statistically significant.

Multiple logistic regression models were constructed to determine the predictive factors for loss of employment. The factors investigated were: claim for compensation; marital status; size of the company; level of education; age; and asthma severity score.

All statistical analyses were performed with Statistical Analysis System (SAS) and Biomedical Data Package (BMDP) software packages.

\section{Results}

The sociodemographic characteristics of the 209 patients are presented in table 1 . The mean age at the time of diagnosis was 38 yrs (range 16-60 yrs). Most subjects were male. A large proportion of patients were employed in small companies with few employees. The diagnosis of occupational asthma was often late, as the mean duration of symptoms before diagnosis was greater than 3 yrs (range 0-12 yrs). One hundred and twenty four had filed a claim for compensation. At time of review, 103 (83\%) cases had been recognized and compensated.

Causative agents of occupational asthma are presented in table 2. Flour and isocyanates were by far the most frequent agents. The high prevalence of flourrelated asthma is explained by the large number of bakeries in France.

Table 3 depicts employment outcome. At time of follow-up assessment, 117 patients $(56 \%)$ were still working for the same employer, 20 of whom still held the

same job and 46 of whom held the same job with improved ventilation or more appropriate individual respiratory protection. This means that 66 patients $(32 \%)$ remained exposed to the offending agents. Thirty eight had alternative work in the same workplace and were no longer exposed. Eighty five had left their previous employer, $75 \%$ of these as a result of their occupational asthma.

Table 2. - Causative agents of occupational asthma

\begin{tabular}{lcr}
\hline Causative agent & $\mathrm{n}$ & Patients \\
& \multicolumn{1}{c}{$\%$} \\
\hline Flour & 48 & 23 \\
Isocyanates & 40 & 19 \\
House dust (acarians) & 16 & 8 \\
Formaldehyde & 15 & 7 \\
Persulphate salts & 14 & 7 \\
Wood dusts & 10 & 5 \\
Animal products & 10 & 5 \\
Metals & 7 & 3 \\
Vegetable products & 6 & 3 \\
Latex & 6 & 3 \\
Aliphatic or aromatic amines & 4 & 2 \\
Soldering fluxes & 3 & 1 \\
Other or undetermined & 30 & 14 \\
\hline
\end{tabular}

Table 3. - Employment status at follow-up

\begin{tabular}{lrr}
\hline Employment status & & Patients \\
& $\mathrm{n}$ & $\%$ \\
\hline Same employer & 117 & 56 \\
$\quad$ Same job & 20 & 10 \\
Same job with protection & 46 & 22 \\
Relocated within firm & 38 & 18 \\
Chronic sick leave & 13 & 6 \\
Unemployed & 52 & 25 \\
New employer & 33 & 16 \\
Retired & 7 & 3 \\
\hline
\end{tabular}

Table 1. - Sociodemographic characteristics of the study population and financial consequences of occupational asthma

\begin{tabular}{|c|c|c|c|}
\hline Characteristics & $\begin{array}{l}\text { Total group } \\
(\mathrm{n}=209)\end{array}$ & $\begin{array}{l}\text { Same employer } \\
\quad(\mathrm{n}=117)\end{array}$ & $\begin{array}{l}\text { Unemployed or } \\
\text { other employer } \\
\qquad(\mathrm{n}=85)\end{array}$ \\
\hline Age at the time of diagnosis yrs & $38 \pm 12$ & $39 \pm 11$ & $35 \pm 12 *$ \\
\hline Male gender \% & 75 & 75 & 75 \\
\hline Duration of symptoms before diagnosis yrs & $3.7 \pm 5.1$ & $3.5 \pm 4.5$ & $4.1 \pm 5.8$ \\
\hline Not married \% & 26 & 19 & $38 * *$ \\
\hline Number of children & $1.4 \pm 1.6$ & $1.6 \pm 1.6$ & $1.2 \pm 1.7$ \\
\hline Nationality other than French \% & 27 & 30 & 23 \\
\hline \multicolumn{4}{|l|}{ Level of education \% } \\
\hline$\leq$ primary school & 34 & 28 & 39 \\
\hline Secondary education & 60 & 63 & 60 \\
\hline Higher education & 6 & 8 & 1 \\
\hline $\begin{array}{l}\text { Size of the company at the time of diagnosis } \\
(<10 \text { employees }) \%\end{array}$ & 35 & 28 & $52 * *$ \\
\hline Claim for compensation $\%$ & 60 & 46 & $79 * *$ \\
\hline Asthma severity score & $5.8 \pm 3.2$ & $5.6 \pm 3.4$ & $5.9 \pm 3.1$ \\
\hline FEV1 \% pred & $88 \pm 20$ & $89 \pm 21$ & $87 \pm 20$ \\
\hline FEV1/FVC \% & $77 \pm 11$ & $77 \pm 11$ & $76 \pm 12$ \\
\hline Patients suffering a reduced income $\%$ & $46(n=186)$ & $19(n=104)$ & $84 * * *(n=82)$ \\
\hline Mean loss of annual income $\%$ & $41 \pm 28$ & $19 \pm 10$ & $50 \pm 28$ \\
\hline
\end{tabular}

\#: subjects who retired $(\mathrm{n}=7)$ are excluded from this group. Data are presented as absolute values or mean \pm SEM. FEV1: forced expiratory volume in one second; FVC: forced vital capacity; \% pred: percentage of predicted value. $*: \mathrm{p}<0.05 ; * *: \mathrm{p}<0.01 ; * * *: \mathrm{p}<0.001$, significance of the comparison between the two subgroups (same employer, and unemployed or other employer). 
Table 4. - Adjusted odds ratios (AOR) for becoming unemployed or having a new employer after the diagnosis of occupational asthma $(n=202)$

\begin{tabular}{lll}
\hline Variable & AOR & $95 \%$ CI \\
\hline $\begin{array}{l}\text { Claim for compensation } \\
\quad \text { No }\end{array}$ & 1.00 & \\
$\quad$ Yes & 6.26 & $2.70-14.5$ \\
$\begin{array}{l}\text { Marital status } \\
\quad \text { Married or cohabitant }\end{array}$ & 1.00 & \\
$\quad$ Unmarried & 1.99 & $0.83-4.78$ \\
Size of the company & 1.00 & \\
$\quad>50$ employees & 4.19 & $1.63-10.80$ \\
$\quad$ 11-50 employees & 4.46 & $1.63-12.30$ \\
$\quad$ 1-10 employees & & \\
Level of Education & 1.00 & \\
$\quad>$ Primary school & 3.37 & $1.38-8.21$ \\
$\quad$ Primary school & 0.94 & $0.91-0.98$ \\
Age $\quad$ Asthma severity score & 1.06 & $0.94-1.19$ \\
\hline
\end{tabular}

95\% CI: $95 \%$ confidence interval.

At time of follow-up, $25 \%$ of the study population were still unemployed, $3 \%$ had retired or had benefited from an early retirement.

Information concerning the financial consequences of occupational asthma was available for 186 subjects. In the whole group, more than $46 \%$ of patients reported that they had suffered from a reduction of income (table 1). Financial consequences and mean loss of annual income were significantly higher in subjects who left their employer than in those who remained in the same company. Of the 103 workers whose claim for compensation was accepted, $58(56 \%)$ suffered from a reduction of income.

When comparing the characteristics of the patients according to their employment status at the time of follow-up (table 1), patients who had lost their initial job were on average significantly younger, more often not married, and more often employed in small companies than those who still had the same employer. They had also more frequently filed a claim for compensation. On the other hand, the two groups did not differ for sex, duration of symptoms before diagnosis, number of children, nationality, and severity of asthma evaluated either by asthma severity score or by pulmonary function tests.

Multiple logistic regression models (table 4), demonstrated that a claim for compensation, the size of the original company, the level of education and age (with a higher risk for young patients), were all significant independent factors associated with the risk of becoming unemployed or having a new employer after the diagnosis of occupational asthma.

\section{Discussion}

The present study has shown that the consequences of occupational asthma in France are considerable in terms of employment and economic status. At the time of follow-up, the unemployment rate for this cohort was $25 \%$, well above that for the general population in France (about $12 \%$ in 1995). More than $40 \%$ had left their employer, and only a small proportion of them had found a new job. As reported previously, the difficulties of finding alternative work in patients with occupational asthma are enhanced by the fact that many of them become unusually sensitive to nonspecific stimuli, such as cold air, dust or irritants, often present at the workplace [12].

Income was also adversely affected. In the whole group, $46 \%$ of the patients reported a reduction of income. Among those who had to leave their original company, $84 \%$ suffered a reduced income. The mean loss of annual income was 50\%. Even some of those patients who remained employed in the same company were financially affected, although to a lesser degree, due to sickness or lack of promotion.

These findings are in agreement with previous studies carried out in the United Kingdom [5, 6, 8], Canada $[4,7]$ and France [3, 9], concerning workers with occupational asthma due either to various agents $[4-6,8-10]$, or to specific agents, such as isocyanates [3] or red cedar [7].

Very few studies have investigated the factors that might affect the employment status in patients with occupational asthma. Our findings suggest that the severity of asthma is not an important determinant of working status. This point has already been emphasized by MARABINI et al. [7], but unlike the latter study we found that subjects who retained employment were older than those who changed company or who were unemployed at the time of follow-up.

In the present study, multiple logistic regression showed that several other independent variables were associated with a risk of becoming unemployed or having a new employer after the diagnosis of occupational asthma had been made. Not surprisingly, it was found that a low level of education, which increased the difficulties of finding alternative work, and a job in a small-sized company, which makes relocation within the firm very difficult, had adverse consequences on employment status.

A claim for compensation was also strongly associated with an increased risk of becoming unemployed. Sixty seven out of 124 patients $(54 \%)$ who claimed compensation had to leave their company, as compared to 18 out of 83 (22\%) who did not do so [13]. However, this study does not allow us to determine whether loss of employment was the cause or the consequence of the claim for compensation. In any case, it is clear that compensation did not match the loss of earnings due to the consequences of occupational asthma on employment, as $56 \%$ of those who were compensated reported a reduction of annual income [13].

In the French compensation system, claims are sent by the workers to the local social security office, accompanied by a medical certificate. The social security office, then carries out a medical and technical investigation. A consulting physician employed by the social security office makes a decision to accept or reject the claim [14]. If the claim is accepted and if workers stop working, they receive a temporary disability compensation, the amount of which varies from 50 to $66 \%$ of salary. When asthma is considered to be stabilized, workers are offered a permanent disability compensation, which is based mainly on the severity of dyspnoea and on the degree of bronchial obstruction. A worker who is definitely 
unable to perform his job and who leaves his employer gets no income replacement indemnity. Possibilities of retraining for a new job are poor, and limited in practice to workers under 40 yrs of age.

This inadequate compensation may have contributed to the decision of some worker to remain exposed after the diagnosis. In the present study, at the time of follow-up, nearly one third of the patients were still exposed to the aetiological agents responsible for their asthma. Financial consequences were nil or minor but their condition was likely to worsen [15-17]. Two thirds of the patients were no longer exposed but most of them suffered a marked reduction of income. Such a situation is unsatisfactory, both from a medical and from an economic point of view, as it reflects an obvious conflict between health and employment. Several studies have shown that occupational asthma can lead to permanent disability, even after removal from exposure to the occupational sensitizer $[15,18]$. However, it has been proved that subjects who stayed in the same job generally experienced a worsening of their asthma and an increase in nonspecific bronchial hyperresponsiveness [15-17]. Complete and early removal from exposure, therefore, remains the treatment of choice in patients with occupational asthma.

Following the example of the procedure adopted in Quebec, Canada [14, 19], efforts should be made to increase and improve retraining programmes, and to provide an income replacement indemnity, ensuring that there is no loss of income during the rehabilitation period.

\section{References}

1. Meredith S. Reported incidence of occupational asthma in the United Kingdom, 1989-1990. J Epidemiol Community Health 1993; 47: 459-463.

2. Contreras GR, Rousseau R, Chan-Yeung M. Occupational respiratory diseases in British Columbia, Canada, in 1991. Occup Environ Med 1994; 51: 710-712.

3. Rosenberg N, Garnier R, Rousselin X, Mertz R, Gervais $P$. Clinical and socioprofessional fate of isocyanateinduced asthma. Clin Allergy 1987; 17: 55-61.

4. Yassi A. Health and socioeconomic consequences of occupational respiratory allergies: a pilot study using workers compensation data. Am J Ind Med 1988; 14: 291-298.
5. Venables KM, Davison AG, Newman-Taylor AJ. Consequences of occupational asthma. Respir Med 1989; 83: 437-440.

6. Gannon PFG, Weir DC, Robertson AS, Burge PS. Health employment and financial outcomes in workers with occupational asthma. Br J Ind Med 1993; 50: 491-496.

7. Marabini A, Dimich-Ward H, Kwan SYL, Kennedy SM, Waxler-Morrison N, Chan-Yeung M. Clinical and socioeconomic features of subjects with red cedar asthma: a follow-up study. Chest 1993; 104: 321-324.

8. Cannon J, Cullinan P, Newman Taylor A. Consequences of occupational asthma. BMJ 1995; 311: 602603.

9. Kopferschmitt-Kubler MC, Gassmann V, Blaumgiser M, Nisand G, Pauli G. Outcomes of 55 cases of occupational asthma. Eur Respir J 1995; 8 (Suppl. 19): 301s.

10. Tarlo SM, Liss G, Corey P, Broder I. A workers compensation claim population for occupational asthma: comparison of subgroups. Chest 1995; 107: 634-641.

11. Blanc PD, Jones M, Besson C, Katz P, Yelin E. Work disability among adults with asthma. Chest 1993; 104: 1371-1377.

12. Lagier F, Martin F, Charpin D, Vervloet D. Sous déclaration des cas d'asthme professionnel dans la région Provence-Alpes-Côte d'Azur et la Corse. Rev Mal Respir 1991; 8: 209-212.

13. Ameille J, Devienne A, Brochard P, et al. Réflexions sur l'indemnisation des asthmes professionnels: à propos d'une étude multicentrique réalisée en lle-de-France. Arch Mal Prof (in press).

14. Dewitte JD, Chan-Yeung M, Malo JL. Medicolegal and compensation aspects of occupational asthma. Eur Respir J 1994; 7: 969-980.

15. Chan-Yeung M, Malo JL. National history of occupational asthma. In: Bernstein IL, Chan-Yeung M, Malo JL, Bernstein DI, eds. Asthma in the Workplace. New York, M. Dekker Inc., 1993; pp. 299-322.

16. Pisati G, Baruffini A, Zedda S. Toluene diisocyanate induced asthma: outcome according to persistence or cessation of exposure. Br J Ind Med 1993; 50: 60-64.

17. Cote H, Kennedy S, Chan-Yeung M. Outcome of patients with cedar asthma with continuous exposure. $\mathrm{Am}$ Rev Respir Dis 1990; 141: 373-376.

18. Paggiaro PL, Wagaggini B, Bacci E, et al. Prognosis of occupational asthma. Eur Respir J 1994; 7: 761-767.

19. Malo JL, Dewitte JD, Cartier A, et al. Le système québecois d'indemnisation pour asthme professionnel: description, efficacité et coûts. Rev Mal Respir 1993; 10: 313-323. 